\title{
Communications and Arts
}

\author{
Nguyen Minh Quang \\ College of Fine Arts, Shanghai University, China \\ nguyenminhquang8@sina.com
}

Keywords: Arts; Information technology; Communications and aesthetic concepts.

\begin{abstract}
Science and information technology today has been developing very fast, especially social networking applications such as Facebook, YouTube, WeChat... That has created a huge impact changing political, cultural, social and artistic life in Vietnam today. In this article, I just mention one issue that is: How does information technology impact on our life of thinking and aesthetic concepts?
\end{abstract}

\section{Introduction}

When discussing the transformation of the world in recent years, author Thomas L. Friedman in his book "The World is Flat" wrote: "The role of new communications through Internet connection, mobile communications, and other forms of personal digital assistants - as one of the most fundamental factors makes the world become "flat"' [1-3]. The new communications technology not only develops technically but also affects the fundamental changes in perception of the whole society as well as changes in the theory of social managers. The development and application of new communications in today's society are diverse, multi-dimensional and increasingly rich.

\section{Current Situation of Communications in Vietnam}

In spite of appearing in Vietnam not long, the new communications has made a significant impact on the cultural life of the people, especially the residents in the big cities such as Hanoi and Ho Chi Minh City.

According to new figures published by the Internet World Stats, by the end of June 2015, Vietnam had 45.5 million Internet users, reaching a penetration/population rate as $48 \%$. The hereinabove number of users access the Internet with all supported media (PC, laptop, cell phone ...) [4-7]. With this figure, Vietnam is ranked the sixth in Asia in the number of users, following China (674 million), India (354 million), Japan (114.9 million), Indonesia (73 million), the Philippines (47.1 million) and is the 17th country out of 20 countries with the most internet users in the world [8-10].

And that figure is constantly increasing at a rapid pace in the coming time. The influence of new communications on the living habits of each people in particular and the entire social life in general is huge, and it certainly would be one cause to the change in artistic practices in Vietnam.

\section{Impact of Information Technology on the Arts and Cultural Life}

Information technology and communications now have such roles because: 1) Currently, the use of mobile communications has become massive and popular in the Vietnamese society. The fact shows that regardless of the social status or economic circumstances, each individual has equal opportunity in the use of new communications to enrich their cultural knowledge. Thanks to these media, individuals have crossed the national borders, territories and thereby gain access to all the achievements of human civilization, including art. In other words, the limitations of the economic context and politics of a country do not specify the aesthetic trends and public perception of art in Vietnam today any longer. Therefore, over the last years a lot of new things in arts have appeared much more than ever before. Just by going through art events in recent years we can see modern art, contemporary art, and multi-media art such as video art, installation, and performance art, etc. in Vietnam. It is worth mentioning here that all things which are considered new in art practices in 
Vietnam as stated above are not or have not been taught officially in the art institutions in Vietnam. Then where are such knowledge, ideas and skills of artistic creation acquired from if it is not from the internet?

2) The use of new communications is becoming increasingly popular as a forecast of individualization, in which individuals in society are looking forward to showing their own ego, freedom of thought and actions. It is individualization which changes fundamentally the forms and methods of cultural activities of the people at the present. First of all, the powerful individualization weakens the strength of the traditional symbols from politics, society to arts and culture. When Internet is not popular globally, each society, each nation often maintains cultural values and separate art standards, holding the independent symbols. These symbols not only unify mind and actions of individuals in a society, but also are like a social pressure under orders. That leads to a corollary: Those who do not comply with "orders" of those symbols are considered as "minorities", as "deviant". It is such symbol, such value system which becomes aesthetic reference for art creativity and consumption. This explains why we often distinguish works of art with high or low quality, erudite or common, distinguish healthy versus vile tastes or exquisite versus vulgar tastes.

When the market economy prevails and individualism is established and develops, personal preferences or personal tastes satisfying the individual needs will be placed on top. Even this becomes an aesthetic value in the modern society. From this reality, in contemporary art there are new phenomena such as art standards which are categorized into high-low, erudite-common, and traditional-modern are gradually rejected, even the boundary between art and everyday life is blurred.

Also it is necessary to add that communications facilitates the new approach to art. Today, through the internet the works can go straight away, directly to the audience without any intermediary (such as introduction, criticism, or censorship). Thus, the art audience is absolutely respected. They can perceive and evaluate the works with their own sense and experience. This also explains the ambiguity and multi-functionality of contemporary art.

3) On the other hand, thanks to individualization, individuals can connect with the others who have the same interests, tastes, political and social views, and even economic links. These links is to create a special community. These links is to create a special community. (The researchers call it Textual and Oral Communities). "If previously the mass media was old, the information is transmitted one-way, individuals have little chance of interaction, especially "at-the-bottom" or "minority" social groups, but now, thanks to the new communications, minority groups are "empowered" and have more "voice" to the community. Although this reverse connection is limited to textual and oral communities, it is strong enough to weaken "spiral of silence" [11-12]. We can say that new communications actively promotes the process of social democratization. Thus, social life becomes more democratic, more multidimensional and cultural life becomes richer and more diverse, not one-way anymore.

\section{Social Effects of Information Technology}

Today, the availability of modern communications has significant impact on the demolition of one-way nature in cultural and art life in Vietnam. Now, everyone has the opportunity to share thoughts, aspirations and their ideas no matter whether their opinions are socially acceptable or not. If their opinions are not published in the mainstream communications, then they can write a blog or use Facebook, YouTube, and WeChat, etc. to share private photos, new concepts, or unique ideas, etc., which are gradually accepted and shared by the networking community. Its influence in fact is not inferior to other forms of communications. Many examples in the world and in Vietnam show that sometimes the minority opinion prevails in a society more and more open to the difference in opinion. The mass media has now voluntarily or "is forced" to post personal opinions to satisfy global trend.

Also in the art, previously mainstream art values were realism and socialist realism which were subsidized and supported by government, highly promoted by the academics and obviously became common aesthetic value which individuals in the society had to follow. And indeed, for a long time, 
the majority of art public in Vietnam has "voluntarily" perceived such aesthetic ideal. Today, social reality has changed, and of course art must also change accordingly. At the moment art public in Vietnam can get access to cultural knowledge and art theory from the internet. They choose aesthetic concepts for their own which are not limited by aesthetic value as provided and imposed by the Vietnamese political apparatus. Apparently, currently the government still focuses on subsidies and encourage mainstream art communication activities and does not encourage or support the various forms of new art communications. It is really a regrettable delay.

\section{Conclusion}

Consequently, even in Vietnam, the actual perception of art has changed, and it requires a change in theory accordingly.

First is to redefine the connotations and characteristics of art concepts. Of course, at the moment putting art on the same par with politics is outdated and everyone realizes it. However many art academics in Vietnam still conserves the traditional art concepts, in which art is identified the same as the artworks. This concept is that artworks is the center. The limit of this concept is that it does not reflect the process of production, consumption of art, ambiguity and multi-functionality of the art, the diverse aesthetic object, the non-aesthetic relations in the overall structure of the art and especially art always has to depend on the value scale of contemporary society.

I always believe that when theory about art develops, artistic practices will develop accordingly or otherwise they will be trapped, crippled.

\section{References}

[1] Thomas L. Friedman "The World is Flat”, World publisher. 2006.

[2] http://xahoithongtin.com.vn.

[3] Bui Quang Thang “30 terms of cultural studies”, Social Sciences Publishing House, Hanoi, 2008.

[4] Liu Xie, Wenxin diaolong, Literature Publishing House, Hanoi, 1999.

[5] Pham Quynh, source: http:// Chungta.com. Little discussion of aesthetics: What is Beauty?

[6] Nikolai Chernyshevsky The Aesthetic Relation of Art to Reality, Literature - Art Publishing House, Hanoi, 1962.

[7] Lenin discusses literary culture, Literature Publishing House, Hanoi, 1977.

[8] Academy of Sciences USSR (former), an aesthetic principle Marx- Leninism, Part II, Truth Publishing House, Hanoi, 1963.

[9] Taschen, "Art of the 20th Century (Painting-Sculpture-New Media-Photography)", Taschen Publisher, 2000.

[10] Nostalgia, "From Nostalgia towards Exploration-Essays on Contemporary Art in Vietnam", Kim Dong Publishers, 2005.

[11]Duong Tuong, "Vietnam Express, Contemporary Art From Vietnam", Fine art publishing house, 1997.

[12] Thomas L. Friedman "The Lexus and the Olive tree", Social Sciences Publishing House, Hanoi, 2005. 